\title{
MISIUNE ȘI SECULARIZARE ÎN VIZIUNEA LUI ANASTASIE YANNOULATOS
}

\author{
Ion DRAGNE*
}

\begin{abstract}
Mission and secularisation in the vision of the theologian Anastasios Yannoulatos ${ }^{1}$. The present study aims to emphasize the requirements of the Christian mission from an Orthodox Christian perspective in the context of the multi-pluralist and secularized contemporary world. Mission is an essential expression of Orthodox self-conscience, shout out for the fulfilment of God's wil "on earth as it is in heaven". Secularization, globalization, technologization, virtualization of society requires a responsible response from ourselves, as Christians. First of all, if we believe that human life is a gift from God, an invaluable gift, then we have to defend it from the beginning and the end of it. We cannot accept, for example, that the costeffectiveness of the health system is based on eliminating those whose physicians do not give them any chance. That is why I think it is important to have the strategies of human rights founded on the dignity of the human person, which is created in the image of God. Then the economy, like politics, must serve directly to man. And when I say to man, I do not mean the few people, the strong and the rich, but the most of the population, even the most fragile of us. And the most helpless man must have the chance of a dignified existence in European society. That is why we, as Christians, must to support, at European level, a social economy which main purpose is the real welfare and policies based on serious social investments that take care of those in need. In my opinion, through education and culture, we can form Christians, and the Church and its mission play an important role in this area.
\end{abstract}

“Priest, PhD Student, Faculty of Orthodox Teology at „1 Decembrie 1918” University, Alba Iulia, Romania.

1 Studiu redactat sub îndrumarea Prof. Univ. Dr. Habil. Daniel Munteanu, care şi-a exprimat acordul pentru publicare. 
Keywords: mission, secularization, self-conscience, technology, God.

\section{Introducere}

Biserica este astăzi instituţia care trebuie să dea un răspuns adecvat la nevoile și la provocările lumii, să ofere un mijloc de depăşire a acestora şi să propună un mod de viaţă care are ca ,,pietre de temelie”: iubirea, comuniunea, solidaritatea, pacea, speranța, elemente esențiale care aduc echilibru și bunăstare în societate.

Misiunea creștină, ca mijloc de extindere în istorie a Trupului lui Hristos, de propovăduire a valorilor evanghelice și de lărgire a comuniunii ecleziale, se află înaintea unor situații cu totul noi, în care secularismul, materialismul, consumismul ori indiferentismul religios provoacă speranța a numeroase comunități creștine, unora provocândule o teribilă angoasă, altora pierderea credinței sau, dimpotrivă, întărindui în propria lor mărturisire².

Misiunea ortodoxă are în centrul mesajului ei dorința de a oferi lumii tradiția vie a Bisericii, parfumul vieții apostolice, felul în care, din întâlnirea Evangheliei cu totalitatea valorilor spirituale și materiale ale omenirii și cu civilizația spațiilor locuite astăzi de ortodocși, a răsărit o frumoasă cultură duhovnicească, s-a sedimentat o puternică credință și a înflorit un autentic mod de viață creștin ${ }^{3}$.

Cuvântul ,misiune”, în concepția părintelui arhiepiscop Anastasios Yannoulatos, este înţeles ca fiind mărturisirea pentru Dumnezeul Treimic Cel Viu, care ne cheamă la mântuire şi îi leagă pe oameni cu Biserica, oamenii care nu aparțin acesteia sau care au pierdut legătura cu ea. Acesta afirmă că este nevoie de misiune nu doar în regiuni îndepărtate, ci în întreaga lume, pe toate continentele ${ }^{4}$. Biserica cea „una, sfântă, sobornicească și apostolică"5 are menirea să mărturisească oamenilor, atât din zonele de aproape, cât și din cele îndepărtate, cuvântul lui Dumnezeu

2 Nifon MıнĂIȚĂ, Teologie, Cultură și Dialog Inter-Religios în Misiunea Bisericii, Târgoviște, Edit. Bibliotheca - Valahia University Press, 2014, p. 158.

3 Ion BRIA, Tratat de Teologie Dogmatică şi Ecumenică, Bucureşti, Edit. România Creștină, 1999, p. 258.

${ }^{4}$ Vezi: Anastasie Yannoulatos, Misiune pe urmele lui Hristos, trad. Ştefan L. Toma, Sibiu, Edit. Andreiana, 2013, p. 197.

5 Articolul al IX-lea din Simbolul de credință niceo-constantinopolitan. 
cel Viu și să arate egalitate față de etnii sau față de statutul social, căci tot ce ține de ființa umană nu este în afara misiunii creștine.

Este foarte bine știut faptul că misiunea Bisericii implică dialog interconfesional, esențial și fundamental, izvorât din însăși vocația sa de așezământ divino-uman, dar și din dorința expresă a Mântuitorului Hristos, „ca toți să fie una”. Relația dialog-misiune este înțeleasă din conceptul de misiune ca „Missio Dei”, pentru că Însuși Dumnezeu este originea misiunii ${ }^{6}$. În înțelegerea conceptului de misiune din „Missio Ecclesiae” sau „misiunea Bisericii” la Missio Dei, care exclude atitudinea triumfalistă a misiunii. Misiunea lui Dumnezeu are loc în multe feluri și nu este epuizată de misiunea Bisericii. Oamenii care țin de alte confesiuni sau chiar ateii pot fi agenți ai Missio Dei. Astfel, dialogul este esențial pentru a discerne focalizarea și forma Missio Dei în lume. În acest sens, atât misiunea Bisericii, cât și dialogul interconfesional, trebuie văzute ca răspunsuri la Missio Dei și astfel, ca arene pentru lucrarea Duhului Sfânt ${ }^{7}$.

Misiunea Bisericii trebuie sprijinită, fundamentată pe teologie, deoarece ea este o necesitate universală, nu doar locală; Perceperea misiunii în lumina Revelației și în special a Tainei Sfintei Treimi are o importanță fundamentală pentru întreaga Biserică ${ }^{8}$.

Din moment ce Biserica este ,extinderea lui Hristos peste veacuri" ", noi, credincioșii, participăm la misiune fiind parte a unui plan dumnezeiesc, care se desfășoară în prezent și are dimensiuni cosmice.

Plpecând de la aceste premise, lucrarea noastră caută sp clarifice rolul misiunii creștine în lumea secularizată de astăzi, provocările misionare la care este supusă Biserica, precum şi răspunsul pe care teologul contemporan Anastasios Yannoulatos le oferă în acest sens.

\section{Misiune și Secularizare astăzi}

Fenomenul secularizării a fost analizat, descris și definit în ultimii ani într-o mulțime de feluri, dar nici una dintre aceste descrieri nu a subliniat un punct de vedere esențial și care relevă într-adevăr mai bine

6 Christopher Duraisingh, „Issues in Mission and Dialogue: some reflections”, în International Review of Mission, Vol. 77, No. 307, 1988, p. 405.

${ }^{7}$ Ibidem, p. 405.

${ }^{8}$ A. Yannoulatos, Misiune pe urmele lui Hristos, p. 213.

${ }^{9}$ Ibidem, p. 214. 
decât orice altceva adevărata natură a secularizării. Secularizarea este, mai presus de toate, o negare a cultului. Subliniez că nu se neagă existența lui Dumnezeu sau religia ${ }^{10}$. Dacă secularizarea, în termeni teologici, este o erezie, aceasta este în primul rând o erezie ${ }^{11}$. Este negarea omului ca ființă față de cult, ca „homo adorans”, întrucât închinarea este un act esențial care îi stabilizează umanitatea și o întregește. Este respingerea, atât din punct de vedere ontologic, cât și din punct de vedere epistemologic, „decisivă”, pretutindeni și pentru toți, este adevărata „epifanie" a relației omului cu Dumnezeu și a lui Dumnezeu cu omul ${ }^{12}$.

Teologul Anastasios Yannoulatos subliniază nevoia unei teologii profetice, puternice, fundamentată pe o trăire religioasă autentică care să transforme din temelii paradigma lumii noastre. Este adevărat că sunt aspecte ale secularizării cu care nu poți fi foarte conciliant; de exemplu cu problemele legate de deviațiile de gen, cu care nu poți avea o relație prietenoasă. În fața tuturor acestora trebuie reafirmat vechiul principiu patristic conform căruia iubim întotdeauna omul, însă urâm păcatul săvârșit de acesta. $\mathrm{Cu}$ privire la aceste aspecte, teologul grec afirmă:

„Acești factori nereligioși nu trebuie înfruntați ca adversari, ci abordați ca parteneri în înfăptuirea idealurilor universale spirituale care urmăresc înțelegerea și apropierea universală. Ceea ce se cere nu este tutelarea sau crearea unui front comun al religiilor împotriva altor forțe, de tipul cruciadelor, ci o contribuție substanțială la abordarea circumstanţelor nou create"13.

Când vorbește despre dezvoltarea misiunii ortodoxe în vremea noastră, Arhiepiscopul Anastasios consideră că trebuie avute în vedere două aspecte de importanță fundamentală: în primul rând, dezvoltarea gândirii teologice a misionarului, în sensul progresului şi al conștientizării, deci, pe cât posibil, între toți membrii Bisericii, căci misiunea este o manifestare fundamentală a conștiinței noastre ecleziale și, prin urmare, această certitudine trebuie transmisă Bisericii noastre, iar

${ }^{10}$ Alexander Schmemann, Worship in a secular age, St. Vladimir's Seminary Press, printed in USA, 1973, p. 118.

${ }^{11}$ Ibidem, p. 118.

12 Ibidem, p. 118.

13 Anastasios Yannoulatos, Ortodoxia și problemele lumii contemporane, București, Edit. Bizantină, 2003, p. 20. 
în al doilea rând, un studiu serios al modernului, al lumii secularizate și pluraliste de astăzi, lume care necesită o analiză amplă și atentă ${ }^{14}$.

Cheia concepției misionare a teologului grec este conformă principiului treimic al unității în diversitate: unitatea umană poate conviețui în diversitate, fără a depăși granițele permisivității, iar cu privire la acestea părintele Yannoulatos fundamentează misiunea creștină pe activitatea ,ad-extra” dumnezeiască, pe Sfânta Treime, adică pe „Dumnezeu, neapropiatul şi infinitul Dumnezeu Treime, perceput mai ales ca desăvârşită comuniune, ca unitate desăvârșită, nesupusă limitărilor, existență a unei Ființe unitare și, în același timp, participare de Persoane, Unitate în Treime și Treime în unitate"15.

Tot Arhiepiscopul Yannoulatos susține că misiunea și obligația preeminentă a Bisericii este să transmită în fiecare colț al planetei întregul spectru al acestei lumini a Hristosului Înviat, pentru a se împărtăşi toți oamenii din izvorul Cuvântului, iubirea și lumina lui Hristos ${ }^{16}$.

Arhiepiscopul Anastasios amintește despre primii creștini care erau obligați încă de la început să fie în dialog cu membrii celorlalte credințe religioase, pentru a da mărturie despre conștiința de sine și speranțele lor. Astăzi, când dialogul ni se prezintă ca o nouă posibilitatea și provocare, credința ortodoxă este atacată sau disprețuită de credincioșii altor confesiuni, însă este deschisă dialogului inter-religios şi încrezătoare în conștiința de sine și de identitatea $\mathbf{s a}^{17}$.

\section{Participarea liturgică la misiunea Bisericii}

Fiecare dintre credincioși este chemat să continue o „Liturghie” personală în altarul tainic al propriei sale inimi, pentru a avea o viaţă duhovnicească îmbunătățită, „pentru mântuirea întregii lumi”. Fără această continuare, liturghia ar rămâne incompletă. Jertfa Euharistiei trebuie extinsă în sacrificii personale pentru oamenii în suferință, frații pentru care Hristos a murit... Continuarea liturghiei în viaţa cotidiană înseamnă o eliberare continuă de puterile răului care lucrează în noi, o

\footnotetext{
${ }^{14}$ A. Yannoulatos, Misiune pe urmele lui Hristos, p. 170.

${ }^{15}$ IDEM, Ortodoxia și problemele lumii contemporane, p. 24.

${ }^{16}$ IDEM, Sharing the Good News in a Multi-Religious Country, New York City, Fordham University, 2014, p. 20.

${ }^{17}$ IDEM, Misiune pe urmele lui Hristos, p. 227.
} 
reorientare neîntreruptă și o deschidere către idei și eforturi care vizează eliberarea ființei umane de toate structurile demonice, de nedreptate, exploatare, agonie, singurătate și în cele din urmă, concretizarea tuturor acestora într-o comuniune reală a iubirii ${ }^{18}$.

„Prioritatea noastră trebuie să fie dezvoltarea unei vieți liturgice dinamice în spiritualitatea ortodoxă. Am insistat asupra acestui principiu formulat de Mișcarea Ecumenică în anul 1974, «Liturghia după Liturgie», adică întreaga noastră viață ar trebui transformată într-o «Liturghie personală», în care trebuie să mulțumim împreună cu semenii noștri pentru darurile date de Dumnezeu" ${ }^{\prime \prime}$.

Punctul constant de plecare pentru orice apreciere a acestui subiect este, în primul rând, certitudinea că slava lui Dumnezeu legată de pronia Lui radiază în lume prin energiile divine pentru întreaga creație, în special pentru umanitate. În al doilea rând, toate ființele umane, au o origine comună, au o singură natură umană și aceeași destinație. Credința creștină accentuează faptul că Dumnezeu este de neconceput, necunoscut și inaccesibil în ființa Sa. În același timp, totuşi, revelaţia biblică transcende impasul naturii incomprehensibile a lui Dumnezeu Tatăl, clarificând faptul că, în timp ce esența lui Dumnezeu rămâne necunoscută, prezența divină este revelată în mod activ în univers prin intermediul manifestării energiilor divine. Când Dumnezeu este descoperit prin diverse epifanii, nu este vorba despre esența lui Dumnezeu, ci despre slava Sa care se arată pentru că numai ea poate fi împărtășită prin har ${ }^{20}$.

În cele din urmă, ce este Biserica? Nu suntem pur și simplu un grup de credincioși pioși ai Lui Hristos. Suntem membri ai Trupului lui Hristos, „Biserica, plinătatea Lui care completează totul”. Ce se realizează în noi atunci când primim Trupul și Sângele lui Hristos? În această taină nu oferim doar o penitență individuală, ci devenim mădulare vii ale Trupului mistic al lui Hristos - ființe care gândesc, suferă și acționează ca El. În aceasta constă înțelegerea problemei esențiale a conștiinței noastre de sine. Fiecare comunitate eclezială trebuie să

${ }^{18}$ Ion BRIA, ,The Liturgy after the Lyturgy”, în Orthodox Perspectives on Mission, edited by Petros Vassiliadis, Regnum Edinburgh Centenary Series, Vol. 17, 2013, p. 46.

${ }^{19}$ Ibidem, p. 46.

${ }^{20}$ Anastasios Yannoulatos, Misiune pe urmele lui Hristos, p. 12. 
participe la responsabilitatea universală a Bisericii, rămânând în același timp în cea locală. În fiecare situație concretă, Biserica locală reprezintă ceva specific, prin care îl slăvește pe Dumnezeu și își oferă mărturia. În același timp, însă, este necesar ca elementul local, împreună cu aspectul universal, să fie experimentat într-un mod corespunzător de fiecare eparhie și de fiecare parohie ${ }^{21}$.

Pentru a fi mereu un martor viu al prezenței lui Dumnezeu, misionarul trebuie să fie într-o continuă relaţie personală cu El. Creştinul trebuie nu numai să se gândească sau să vorbească despre El, ci să „trăiască în Hristos” (Gal. 2, 20). Aceasta înseamnă să aibă o relație strânsă cu Hristos din toată fiinţa sa, nu doar din intelectul său. Este transformarea întregii ființe în Hristos, care este adevărata menire a misionarului ${ }^{22}$.

\section{Concluzii}

Evoluția societăţilor democratice contemporane sugerează că încă este timp pentru definirea sensului și scopurilor secularismului. Încă din timpul Fericitului Augustin și până în perioada modernă relația dintre puterea temporală și spirituală a fost primordială, dar provocările epocii prezente sunt de o natură diferită. Contextul misionar în care ne aflăm este marcat de procesul de secularizare cu complexitatea deosebită a subproceselor și implicațiilor sale. Acest lucru ridică probleme specifice misiunii Bisericii, căci pe de o parte este vorba de situații noi, care cer un răspuns adecvat, iar pe de altă parte este vorba de gestionarea unor realități, unor fenomene și elemente sociale cu care Biserica, în forme diferite, dar cu conţinut similar, s-a mai confruntat în trecut. Întreaga lume, întreaga creaţie, nu doar umanitatea, ci întregul univers participă la restaurare, care a fost înfăptuită de Iisus Hristos prin răscumpărarea pe cruce și care își găsește din nou destinația în slava lui Dumnezeu. Misiunea este extinderea iubirii Sfintei Treimi pentru transformarea întregii lumi. Ca membri ai Bisericii, cu daruri unice pe care Dumnezeu

21 IDEM, The Apostolic responsibility and worldwide dimension of the Orthodoxy, Syndesmos Festival 2001, Saint-Maurin, France, 30th August 2001, p. 6.

${ }^{22}$ IDEM, The Missionary Activity of the Orthodox Church, 6th General Assembly, Punkaharju, Finland, 30/07-03/08 1964, p. 14. 
ni le-a dat, să producem o adevărată sete în oameni pentru adevărul Evangheliei. Ceea ce căutăm sunt perspective misionare deschise prin care trebuie să împărtăşim celorlalți viața dumnezeiască a Sfintelor Evanghelii ${ }^{23}$.

În concluzie, vedem că este de neconceput pentru Biserica Ortodoxă să nu aibă în continuare slujire în lume la fel cum este de neconceput ca ea să nu aibă viață misionară.

\section{Referinţe bibliografice:}

1. BRIA, Ion, Tratat de Teologie Dogmatică și Ecumenică, Bucureşti, Edit. România Creștină, 1999;

2. BRIA, Ion, „The Liturgy after the Liturgy”, în Orthodox Perspectives on Mission, edited by Petros Vassiliadis, Regnum Edinburgh Centenary Series, Vol. 17, 2013, p. 46-59;

3. DuRAISINGH, Christopher, „Issues in Mission and Dialogue: some reflections", în International Review of Mission, 77(307)/988, p. 398-411;

4. HIMCINSCHI, Mihai, „Secularizarea - o problemă contemporană”, în Revista Teologică a Mitropoliei Ardealului, 2/2011, p. 121-132;

5. MıHĂIȚĂ, Nifon, Teologie, Cultură şi Dialog Inter-Religios în Misiunea Bisericii, Târgovişte, Edit. Bibliotheca - Valahia University Press, 2014;

6. Schmemann, Alexander, Worship in a secular age, St. Vladimir's Seminary Press, printed in USA, 1973;

7. Yannoulatos, Anastasie, Misiune pe urmele lui Hristos, trad. Ștefan L. Toma, Sibiu, Edit. Andreiana, 2013;

8. Yannoulatos, Anastasie, Ortodoxia și problemele lumii contemporane, Bucureşti, Edit. Bizantină, 2003;

9. Yannoulatos, Anastasie, Sharing the Good News in a Multi-Religious Country, New York City, Fordham University, 2014;

10. Yannoulatos, Anastasie, The Apostolic responsibility and worldwide dimension of the Orthodoxy, Syndesmos Festival 2001, Saint-Maurin, France, 30th August 2001;

11. Yannoulatos, Anastasie, The Missionary Activity of the Orthodox Church, $6^{\text {th }}$ General Assembly, Punkaharju, Finland, 30/07-03/08 1964.

${ }^{23}$ Mihai HiMCINSCHI, „Secularizarea - o problemă contemporană”, în Revista Teologică a Mitropoliei Ardealului, 2/2011, p. 131. 